УДК 550.422:546.54-:55:502.4:630*238

\title{
ГЕОХИМИЧЕСКИЕ И МИНЕРАЛОГИЧЕСКИЕ ИНДИКАТОРЫ ВЕТРОВОЙ ДЕФЛЯЦИИ НА УРБАНИЗИРОВАННЫХ ТЕРРИТОРИЯХ С ИСПОЛЬЗОВАНИЕМ ЛИСТЬЕВ ТОПОЛЯ
}

\author{
Дорохова Любовь Александровна ${ }^{1}$, \\ liubov.ad@yandex.ru
}

\author{
Юсупов Дмитрий Валерьевич1,2, \\ yusupovd@mail.ru \\ Рихванов Леонид Петрович 1 \\ 1 Национальный исследовательский Томский политехнический университет, \\ Россия, 634050, г. Томск, пр. Ленина, 30. \\ 2 Амурский государственный университет, \\ Россия, 675027, г. Благовещенск, Игнатьевское шоссе, 21.
}

\begin{abstract}
Актуальность работы заключается в необходимости оценки влияния природных и техногенных фракторов окружающей среды на качество атмоссрерного воздуха, почвенно-растительного покрова и на здоровье населения урбанизированных территорий. Процессом разрушения почвенного покрова под действием ветра является ветровая эрозия или дефрляция. Этот процесс широко распространен на территории юга Западной и Восточной Сибири, Дальнем Востоке, особенно в долинах крупных рек, а также в сельскохозяйственных степных районах. Способствуют дефрляии сильные ветра в периоды отсутствия осадков, сухие песчаные отложения по берегам рек, ветроударные склоны, почвы легкого гранулометрического состава, пологий рельеф, создающий условия для беспрепятственного продвижения воздушных потоков. Дефряция может проявлять местный характер, в более активной форме виде пыльных бурь наносить большой вред хозяйству.

Цель работы: оценить роль пылевого загрязнения атмосферного воздуха вследствие дефрляции на урбанизированных территориях путем изучения элементного состава микроразмерных частиц с использованием листьев тополя в качестве биогеохимического планшета.

Meтоды. Элементный состав золы образцов листьев тополя бальзамического (Populus balsamifera L.) изучался методом инструментального нейтронно-активационного анализа, ICP-MS и -AES; элементный состав микроразмерных частиц на поверхности листьев - на сканирующем электронном микроскопе Hitachi S-3400N с помощью энергодисперсионного спектрометра Bruker XFlash 4010; обработка полученных данных проводилась методами многомерного статистического анализа.

Результаты. Представлены результаты исследования минеральной пыли из приземного атмосфрерного воздуха, аккумулирующейся на поверхности листьев тополя. Существенный вклад в распределение редкоземельных элементов на территории населенных пунктов, расположенных на берегах реки Обь (Колпашево, Каргасок, Стрежевой; озера Байкал (Усть-Баргузин и Северобайкальск), реки Амур (Благовещенск, Хабаровск, Комсомольск-на-Амуре), вносит пылевой фрактор в результате десрляции по направлениям господствующих ветров. С помощью индикаторного $\mathrm{Zr} / \mathrm{Ce}$ отношения определены урбанизированные территории, на которых наблюдается активная ветровая дефлляция. Обнаружены минеральнье частицы легких и тяжелых редкоземельных элементов, преимущественно фоосфаты (моноцит и ксенотим), а также цирконы.
\end{abstract}

\section{Ключевые слова:}

Ветровая эрозия, редкоземельные элементы, Zr/Cе отношение, геохимический индикатор, монацит, ксенотим, циркон, листья тополя, нейтронно-активационный анализ, электронная микроскопия.

\section{Введение}

Интерес к проблеме загрязнения атмосферного воздуха мелкодисперсными взвешенными частицами (particulate matter - PM) возник относительно недавно - в середине 1990-х гг. Распространенность респираторных заболеваний [1], а также аллергии, рака, расстройств центральной нервной систем и т. д. в городской среде постоянно растет [2-4]. Микрочастицы атмосферы урбанизированных территорий имеют разные размеры. Частицы с размерностью 1-2 и 2,5-10 мкм (РМ2.5 и РM10 соответственно) оказывают наиболее негативное влияние на здоровье человека [5]. Это связано главным образом с их высокой проникающей способностью [6]. Была доказана способность частиц с аэродинамическим диаметром менее 10 мкм проникать в бронхиальное дерево, проходить по нему и накапливаться в тканях легких; частицы с диаметром менее 2,5 мкм способны проходить в бронхиолы и альвеолы, а наночастицы с диаметром менее 0,1 мкм (наиболее мелкие) могут проникать в кровоток [7].

Значительное влияние на экологическую ситуацию могут оказывать природные геолого-геохимические факторы. В их число входит геохимическая неоднородность геологической среды, обуславливаемая различными комплексами горных пород и осадочных отложений, которые часто содержат акцессорные минералы и концентраты редкоземельных и радиоактивных элементов [8].

Ветровой эрозии (дефляции) в России подвержены многие регионы. Наиболее активным и наносящим наибольший вред видом ветрового выветривания являются пыльные бури, которые часто наблюдаются в последние годы [9]. Эрозия и ее продукты разрушают верхние слои почвы, что, в свою очередь, приводит к снижению ее плодородия, уменьшению гумусового слоя, развитию оврагов на территориях, заиливанию водоемов и погребению русл рек. Каждый год на территории Рос- 
сии с пахотных склонов сносится >500 млн т плодородной части почв [10].

К природным факторам дефляции относятся: почвы, имеющие легкий гранулометрический состав и легко поддающиеся разрушению; дефицит влажности почвенного покрова; интенсивные ветра, наиболее выраженные в периоды недостатка осадков; изменения температуры или влажности; рельеф местности (ветроударные склоны), в том числе выровненность территорий, что обуславливает свободное продвижение воздушных потоков. Эти факторы не только создают условия для возникновения эрозии, но и определяют возможность и степень ее проявления [11].

Дефляционные процессы динамичны во времени и пространстве [12]. Это зависит не только от природных факторов, но также и от эффективности противоэрозионных мероприятий [13]. Наиболее активная ветровая деятельность наблюдается главным образом в весенний и летний периоды, и зависит от климата. В засушливые периоды она усиливается [14]. Древесные растения играют значимую роль в снижении ветровой эрозии. Они способны не только «укреплять» поверхность почв, защищая ее от ветра, но и влиять непосредственно на саму скорость ветра [15].

Процессы эрозии, выветривания и осаждения способствуют загрязнению редкоземельными элементами (РЗЭ) почвы, донных отложений, воды и воздуха. Группа РЗЭ является предметом научного интереса геологов, геохимиков, геоэкологов. РЗЭ обладают уникальными физико-химическими свойствами, могут находиться в форме оксидов, карбонатов, металлов [16]. С учетом низких концентрационных свойств в отношении процессов переноса и преобразования в атмосфере РЗЭ являются надежным и мощным инструментом для геохимической характеристики районов с запыленностью [17].

По литературным данным РЗЭ могут оказывать положительное воздействие на живые организмы, например, на регенерацию тканей и на биохимические процессы в растениях [18-20]. Однако при высоких концентрациях РЗЭ становятся токсичными, нарушают кальциевый обмен. РЗЭ обладают значительным потенциалом накапливаться в органах и тканях нервной системы [21]. Лантаноиды способны вызывать гранулематозные поражения легких, пневмокониоз [22-24], что создает угрозу для здоровья населения. Поэтому изучение минеральных форм, содержащих Р3Э, имеющих как техногенный, так и природный генезис, имеет большое значение.

Таким образом, оценка влияния природных факторов на окружающую среду, определение содержания химических элементов и их минеральных форм нахождения являются важными задачами изучения экологического состояния урбанизированных территорий. РЗЭ являются индикаторами для геохимической характеристики пылевого загрязнения территорий [25]

Цель данного исследования - оценить роль пылевого загрязнения атмосферного воздуха вследствие дефляции на урбанизированных территориях путем изучения элементного состава микроразмерных частиц с использованием листьев тополя в качестве биогеохимического планшета.

\section{Материалы и методы}

Объектом исследования являются листья тополя бальзамического (Populus balsamifera L.), т. к. листья являются природным планшетом, способным улавливать и задерживать палеаэрозоли из атмосферы [26, 27]. Предмет исследования - элементный и минеральный состав частиц на поверхности листвы тополя.

Среди природных объектов можно использовать листья растений в качестве биогеохимического индикатора загрязнения приземного атмосферного воздуха $[28,29]$. Доказано, что листва деревьев эффективно улавливает пылеаэрозоли [30, 31]. Эта экосистемная функция наземных растений обеспечивает сокращение уровня концентрации мелкодисперсных частиц в воздухе, снижая негативное влияние на дыхательную и сердечно-сосудистую системы человека [32].

К самым значимым преимуществам листьев тополя можно отнести их морфологическое и анатомическое строение листовой пластины: наличие клейкого воска, шероховатую поверхность, специфическое расположение устьиц (устьица располагаются на листовой пластине с двух сторон). Листья тополей являются средой, отражающей кратковременный сезонный эффект накопления элементов в течение 4-5 месяцев. Также данный объект позволяет проводить биогеохимическую съемку урбанизированных территорий в различных масштабах по площадной сети [33].

Исследования проводились в 2013-2017 гг. на территории 50 городов. Период сбора материала - конец августа - начало сентября, в фазе наивысшей физиологической активности растений. Образцы листьев отбирали методом средней пробы по окружности в нижней части кроны на высоте 1,5-2 м от земли. Листья помещали в крафт пакеты «Стерит», размером $150 \times 250$ мм. Масса сырого материала составила примерно 100 г.

Листья не промывались водой, чтобы сохранить пылевую составляющую пробы. Подготовка материала листьев для элементного анализа заключалась в его сухом озолении в муфельной печи при $450{ }^{\circ} \mathrm{C}$ в течение 5 часов согласно ГОСТу 26929-94. Затем навеска золы весом $100 \pm 1$ мг паковалась в алюминиевую фольгу.

Для определения содержания РЗЭ в исследуемых образцах проводили инструментальный нейтронноактивационный анализ (ИНАА) по аттестованной методике (НСАМ ВИМС № 410-ЯФ) в аккредитованной ядерно-геохимической лаборатории на исследовательском ядерном реакторе ИРТ-Т в Национальном исследовательском Томском политехническом университете (ТПУ) (аналитик А.Ф. Судыко). Также использовали спектрометрические методы с индуктивно связанной плазмой (ICP MS и AES) в аналитическом центре ДВГИ ДВО РАН, г. Владивосток (аналитик Н.В. Зарубина).

Изучение элементного и минерального состава частиц на поверхности листвы тополя проводилось с помощью сканирующего электронного микроскопа (SEM) Hitachi S-3400N (с приставкой Bruker XFlash 5010 с разрешением 129 еВ для проведения рентгеноспектрального анализа). Приставка обеспечивает обнаружение элементов от бора до америция с пределом 
обнаружения 1 \%. EDS предоставляет информацию об элементах и химических компонентах, составляющих твердые частицы. Данный метод также можно использовать для оценки пыли [34, 35]. При выборе образцов для проведения SEM учитывался геохимический состав проб с высокими концентрациями РЗЭ по имеющимся результатам ИНАА.

Для изучения образцов применялся детектор обратно-рассеянных электронов (BSE) в режиме низкого вакуума (от 50 до 100 Па). Получили информацию о морфологии, химическом составе частиц пыли, также получили карты распределения элементовиндикаторов на поверхности листьев тополя.

Данные для построения розы ветров за период с 31.05.2013 по 01.09.2013 получены с сайта [36] архив погоды с метеостанции г. Благовещенск (аэропорт Игнатьево им. Н.Н. Муравьёва-Амурского).

\section{Результаты и обсуждение}

В процессе изучения геохимических особенностей листьев тополя выделена группа населённых пунктов с высокими концентрациями редких и редкоземельных элементов. РЗЭ содержатся в дорожной пыли $(\mathrm{d} \leq 100$ мкм и
100-2000 мкм) вблизи объектов горнодобывающих предприятий (отвалов и хвостохранилищ) [37]. Их концентрации увеличиваются с уменьшением диаметра частиц [38]. Се используется в качестве легирующего элемента в сварочных электродах [39]. Возможны и природные источники РЗЭ, такие как пыльные бури.

В качестве индикатора, отражающего ветровое природное или техногенное происхождение материала переноса пыли, использовали $\mathrm{Zr} / \mathrm{Ce}$ отношение. Построена диаграмма в координатах $\mathrm{Zr} / \mathrm{Ce}$ (рис. 1). На ней выделяются территории городов, где предполагается влияние ветрового переноса. Так, пылевой фактор наиболее выражен в трех районах: 1) река Обь (Колпашево, Каргасок, Стрежевой; 2) озеро Байкал (УстьБаргузин и Северобайкальск); 3) река Амур (Благовещенск, Хабаровск, Комсомольск-на-Амуре). Особенностью городов, расположенных в долине реки Оби, является наличие открытых мест крутых берегов (ветроударных склонов) - яров. На восточном берегу озера Байкал и в долине среднего и нижнего Амура развиты пологие формы рельефа с песчаными аллювиальными отложениями (косы), которые подвержены дефляции.

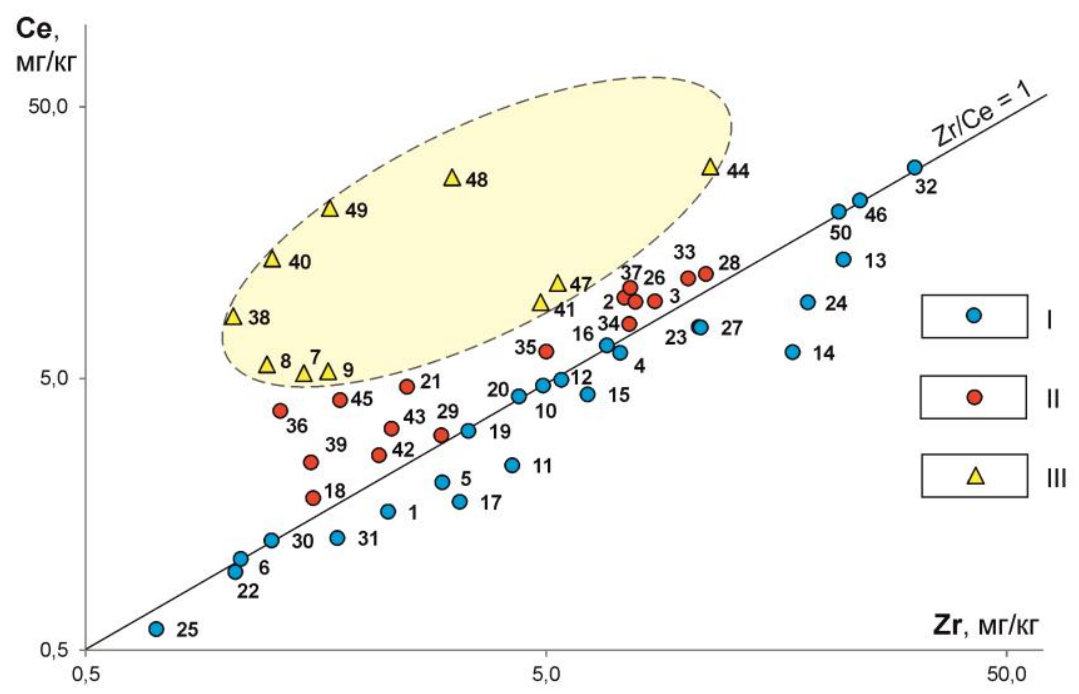

Рис. 1. Соотношение содержания $\mathrm{Zr}$ и Се в золе листьев тополя на исследуемых территориях (Дальний Восток и юг Сибири). Условные обозначения: I- территории с $\mathrm{Zr} / \mathrm{Ce} \geq 1$; II- территории с $\mathrm{Zr} / \mathrm{Ce}<1$; III-mерритории, находящиеся под воздействием природного пылевого фактора среды (прибрежсные речные и озерные пески); 1 - Тюмень, 2 - Тобольск, 3 - Омск, 4 - Новосибирск, 5 - Сургут, 6 - Нижневартовск, 7 - Стрежевой, 8 Каргасок, 9 - Колпашево, 10 - Томск, 11 -Северск, 12 - Асино, 13 - Новокузнеик, 14 - Междуреченск, 15 Белово, 16 - Барнаул, 17 - Заринск, 18 - Белокуриха, 19 - Бийск, 20 - Рубиовск, 21 - Горняк, 22 - Акташ, 23 Красноярск, 24 - Ачинск, 25 - Саяногорск, 26-Абакан, 27 - Черногорск, 28 - Сорск, 29 - Кызыл, 30 - ХовуАксы, 31 - Братск, 32 - Иркутск, 33 - Ангарск, 34 - Шелехов, 35 - Слюдянка, 36 - Закаменск, 37 - Улан-Удэ, 38 - Северобайкальск, 39 - Нижнеангарск, 40 - Усть-Баргузин, 41 - Чита, 42 - район уровской эндемии 6 Забайкалье, 43 - Краснокаменск, 44 - Благовещенск, 45 - Тында, 46 - Якутск, 47 - Нерюнгри, 48 - Хабаровск, 49 - Комсомольск-на-Амуре, 50 - Владивосток

Fig. 1. Ratio of $\mathrm{Zr}$ and Ce content in the ash of poplar leaves in the studied areas (the Far East and south Siberia). Legend: $I$-territories with $\mathrm{Zr} / \mathrm{Ce} \geq 1 ; \mathrm{II}$ - territories with $\mathrm{Zr} / \mathrm{Ce}<1$; III - areas under the influence of the natural dust factor of the environment (coastal river and lake sands); 1 -Tyumen, 2 -Tobolsk, 3 -Omsk, 4 - Novosibirsk, 5 - Surgut, 6 Nizhnevartovsk, 7 -Strezhevoy, 8 - Kargasok, 9 - Kolpashevo, 10-Tomsk, 11 -Seversk, 12 - Asino, 13 - Novokuznetsk, 14 -Mezhdurechensk, 15 - Belovo, 16 -Barnaul, 17 -Zarinsk, 18 -Belokurikha, 19-Biysk, 20-Rubtsovsk, 21 - Gornyak, 22 - Aktash, 23 - Krasnoyarsk, 24-Achinsk, 25-Sayanogorsk, 26-Abakan, 27 - Chernogorsk, 28 Sorsk, 29 - Kyzyl, 30 - Khovu-Aksy, 31 - Bratsk, 32 - Irkutsk, 33 - Angarsk, 34 - Shelekhov, 35 - Slyudyanka, 36 Zakamensk, 37 - Ulan-Ude, 38 - Severobaykalsk, 39 - Nizhneangarsk, 40 - Ust-Barguzin, 41 - Chita, 42 - area of endemic in Transbaikalia, 43 - Krasnokamensk, 44 - Blagoveshchensk, 45 - Tynda, 46 - Yakutsk, 47 - Neryungri, 48 - Khabarovsk, 49 - Komsomolsk-on-Amur, 50 - Vladivostok 
В программе Statistica проведен факторный анализ методом главных компонент, выделены факторы и оценен их вклад (факторы могут быть любого рода: техногенные, природные и т. д.). В результате полу- чены вращаемые факторные нагрузки распределения химических элементов в золе листьев тополя, которые могут интерпретироваться как корреляции между факторами и переменными (таблица).

Таблица. Вращуаемые факторные нагрузки распределения редкоземельных элементов в золе листьев тополя на урбанизированных территориях, подверженных прочессам дефляции

Table. $\quad$ Rotated factor loads of the distribution of rare earth elements in the ash of poplar leaves in urban areas subject to wind erosion

\begin{tabular}{|c|c|c|c|c|c|c|c|c|c|}
\hline $\begin{array}{c}\text { Город } \\
\text { City }\end{array}$ & $\begin{array}{l}\text { Фактор } \\
\text { Factor }\end{array}$ & $\mathrm{La}$ & $\mathrm{Ce}$ & $\mathrm{Nd}$ & $\mathrm{Sm}$ & $\mathrm{Eu}$ & $\mathrm{Tb}$ & $\mathrm{Yb}$ & $\mathrm{Lu}$ \\
\hline \multirow{2}{*}{$\begin{array}{l}\text { Стрежевой } \\
\text { Strezhevoy }\end{array}$} & 1 & 0,95 & $\mathbf{0 , 8 8}$ & 0,63 & $\mathbf{0 , 9 3}$ & 0,92 & $\mathbf{0 , 8 8}$ & 0,72 & 0,13 \\
\hline & 2 & 0,26 & 0,17 & 0,62 & 0,32 & 0,12 & 0,23 & 0,47 & 0,93 \\
\hline \multirow{2}{*}{$\begin{array}{l}\text { Каргасок } \\
\text { Kargasok }\end{array}$} & 1 & $\mathbf{0 , 8 3}$ & 0,61 & $\mathbf{0 , 8 1}$ & 0,78 & 0,84 & 0,72 & 0,52 & 0,61 \\
\hline & 2 & 0,54 & 0,77 & 0,58 & 0,61 & 0,52 & 0,66 & $\mathbf{0 , 8 3}$ & 0,78 \\
\hline \multirow{2}{*}{$\begin{array}{l}\text { Колпашево } \\
\text { Kolpashevo }\end{array}$} & 1 & 0,74 & 0,43 & $\mathbf{0 , 8 8}$ & $\mathbf{0 , 8 9}$ & $\mathbf{0 , 8 7}$ & 0,91 & $\mathbf{0 , 8 1}$ & 0,84 \\
\hline & 2 & 0,63 & $\mathbf{0 , 9 0}$ & 0,45 & 0,45 & 0,49 & 0,40 & 0,56 & 0,51 \\
\hline \multirow{2}{*}{$\begin{array}{l}\text { Северобайкальск } \\
\text { Severobaykalsk }\end{array}$} & 1 & 0,60 & $\mathbf{0 , 7 2}$ & 0,44 & $\mathbf{0 , 8 0}$ & $\mathbf{0 , 8 7}$ & $\mathbf{0 , 8 1}$ & 0,86 & 0,90 \\
\hline & 2 & 0,77 & 0,67 & 0,86 & 0,60 & 0,48 & 0,57 & 0,49 & 0,43 \\
\hline \multirow{2}{*}{$\begin{array}{l}\text { Усть-Баргузин } \\
\text { Ust-Barguzin }\end{array}$} & 1 & 0,46 & 0,13 & 0,86 & 0,79 & 0,73 & 0,64 & 0,78 & 1,00 \\
\hline & 2 & $\mathbf{0 , 8 9}$ & 0,99 & 0,52 & 0,62 & 0,68 & 0,77 & 0,62 & 0,09 \\
\hline \multirow{2}{*}{\begin{tabular}{|l|} 
Благовещенск \\
Blagoveshchensk \\
\end{tabular}} & 1 & $\mathbf{0 , 9 2}$ & 0,94 & 0,14 & 0,92 & $\mathbf{0 , 9 3}$ & $\mathbf{0 , 8 7}$ & 0,76 & 0,54 \\
\hline & 2 & 0,26 & 0,23 & 0,95 & 0,32 & 0,18 & 0,08 & 0,41 & 0,65 \\
\hline \multirow{2}{*}{$\begin{array}{l}\text { Хабаровск } \\
\text { Khabarovsk }\end{array}$} & 1 & 0,86 & $\mathbf{0 , 8 1}$ & $\mathbf{0 , 7 8}$ & $\mathbf{0 , 8 8}$ & $\mathbf{0 , 8 8}$ & $\mathbf{0 , 8 8}$ & 0,51 & 0,34 \\
\hline & 2 & 0,47 & 0,53 & 0,41 & 0,38 & 0,43 & 0,40 & 0,84 & 0,93 \\
\hline \multirow{2}{*}{$\begin{array}{l}\text { Комсомольск-на-Амуре } \\
\text { Komsomolsk-on-Amur }\end{array}$} & 1 & $\mathbf{0 , 8 0}$ & $\mathbf{0 , 8 3}$ & $\mathbf{0 , 8 5}$ & 0,69 & 0,67 & 0,65 & 0,52 & 0,47 \\
\hline & 2 & 0,58 & 0,51 & 0,49 & 0,71 & 0,72 & 0,74 & 0,84 & 0,86 \\
\hline
\end{tabular}

Примечание: жирным шрифтом выделены факторные нагрузки >0,70.

Note: factor loadings $>0,70$ are highlighted in bold.

Первый фактор считается самым значимым. Он включает в себя действие любых процессов, которые способствуют увеличению концентраций большинства элементов в выборке [40]. В результате анализа выявлено, что первый фактор (природный) влияет на содержание практически всей группы РЗЭ в пробах листьев тополя на исследуемых территориях. Это свидетельствует о связи межу этими элементами, а их поступление в атмосферный воздух происходит за счет одного фактора - ветрового переноса.

На примере Благовещенска можно увидеть приуроченность ореолов РЗЭ к поймам и террасам крупных рек. Ореолы с максимальным содержанием РЗЭ наблюдаются вдоль береговых линий рек Амур и Зея, где развиты пологие формы рельефа с сухими песчаными отложениями аллювия (косы), и проявлен ветровой перенос минеральной пыли по розе ветров в результате дефляции (рис. 2).

Наличие высоких концентраций редкоземельных элементов, вероятно, обуславливается влиянием природного фактора [5]. А именно нахождением в атмосфере исследуемой территории большого количества минеральной пыли, состоящей из собственных минералов РЗЭ.

Повышенные концентрации РЗЭ в северозападной части территории можно объяснить близостью водораздела рек Зея и Амур - возвышенности, подверженной эрозии и дефляции (рис. 2 (IV)). Это природный фактор. Противогололедные мероприятия на этой территории проводятся ограниченно, и они существенно не влияют на результаты проведенного исследования. Зимы, как правило, малоснежные, дорожные покрытия остаются сухими. Основное количество осадков выпадает во второй половине лета, в период муссонных дождей, которые нивелируют накопившуюся пыль в зимне-весенний период.

В данной работе уличная пыль и береговые склоны рек не изучались, т. к. это не входило в задачи исследования. Однако по опубликованным данным [41] в твердом осадке снега на территории Благовещенска в осенне-зимний период также были обнаружены минеральные фазы, содержащие редкоземельные элементы, представленные в основном фосфатами легких РЗЭ, по составу близкими к монациту, и карбонатами легких РЗЭ - состав близок бастнезиту.

SEM-EDS исследования предоставили подробную информацию о морфологии и структуре отдельных частиц, а также об элементном составе образцов поверхности листвы тополя. Установлены минеральные фазы, содержащие РЗЭ, характеризующие проявление природного фактора. Данные фазы представлены, прежде всего, фосфатами легких РЗЭ, состав которых близок к монациту, в единичных случаях обнаружены микронные зерна тяжелых РЗЭ минералов, по составу близких к ксенотиму (рис. 3). Во всех городах преобладают минеральные фазы, по составу близкие к монациту-(Се), исключение составляет Усть-Баргузин, где преобладающей формой нахождения РЗЭ является, вероятно, монацит-(La). 

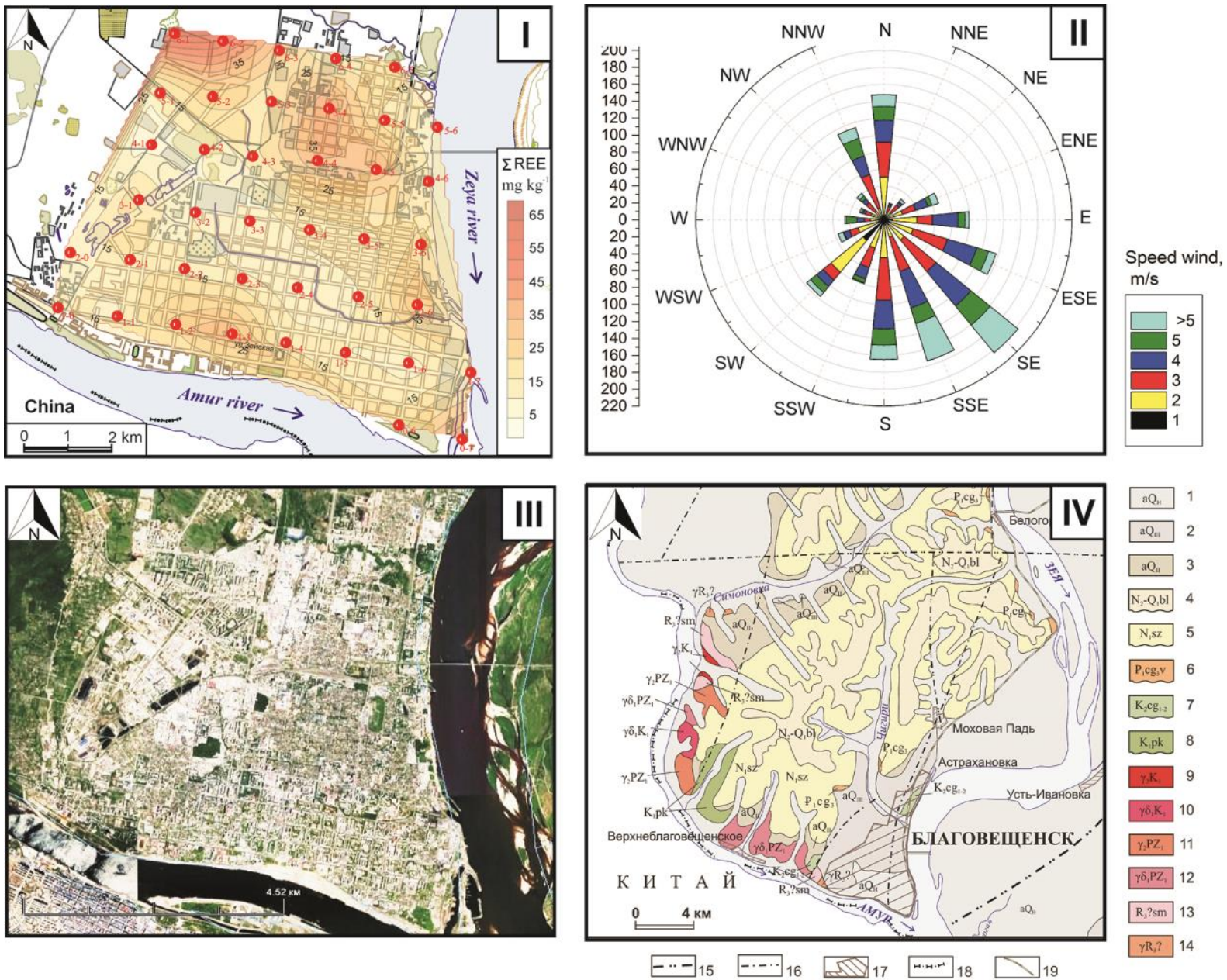

Рис. 2. Проявление дефляции на территории г. Благовещенска: биогеохимические ореоль суммы РЗЭ (I), летняя роза ветров (2013) (II), трансграничная агломерация Благовещенск-Хэйхэ в районе слияния рек Амур и Зея (III). Геологическая карта территории г. Благовещенска и его окрестностей (IV): 1 - голочен; 2, 3 - неоплейстоцен; 4 - белогорская свита; 5 - сазанковская свита; 6, 7 - цагоянская свита; 8- поярковская свита; 9 , 10 - раннемеловые интрузии; 11, 12 - раннепалеозойские интрузии; 13 - позднерифейские интрузии; 14 - симоновкинская толща; 15 - Зейско-Селемджинский глубинный разлом; 16 - разрывные нарушения; 17 - урбанизированная территория; 18 - Государственная граница; 19 - железная дорога

Fig. 2. Wind erosion in the territory of Blagoveshchensk: biogeochemical halos of REE (I), summer wind rose plot for 2013 (II), the cross-border agglomeration of Blagoveshchensk-Heihe in the confluence of the Amur and Zeya (III) rivers. Geological map of the territory of Blagoveshchensk and environs (IV): 1 - holocene; 2, 3 - neopleistocene; 4 belogorskaya formation; 5 - sazankovskaya formation; 6, 7 - tsagoyanskaya formation; 8 - poyarkovskaya suite; 9, 10 - early cretaceous intrusions; 11, 12 - early paleozoic intrusions; 13 - late riphean intrusions; 14 - simonovkinskaya sequence; 15 - Zeisko-Selemdzhinsky deep fault; 16 - breaking violations; 17 - urbanized area; 18 State border; 19 - railroad

SEM-изображения выявили широкий диапазон размеров частиц: самые крупные частицы пыли с РЗЭ обнаружены на поверхности листьев тополя в единичных случаях в Хабаровске (до 20 мкм), преобладающая размерность частиц составила 2-10 мкм. Частицы РЗЭ имеют преимущественно угловатую форму. Некоторые минералы содержали примесь железа 2,7-7,16 \% (рис. 3, в). В статье [42] приводятся примеры структур, которые образовались при участии микроорганизмов. Известно, что железоокисляющие бактерии (хемолитотрофы) способны получать энергию, окисляя $\mathrm{Fe}$ (II) до $\mathrm{Fe}$ (III) [43]. Установлено, что бактерии способны накапливать лантаноиды в концентрациях, которые превышают в миллионы раз концентрации этих элементов в природных средах [35]. Кроме того, встречены и алюмосиликатные частицы с вкрапленностью фосфата редких земель (рис. 4).

Также обнаружены микрозерна, вероятно, циркона (рис. 5). Они имеют преимущественно угловатую форму и меньший размер (>1-3 мкм) по сравнению с Р3Э. Редкие зерна циркона имели размер до 7 мкм, правильную и неправильную формы. В некоторых зернах циркона встречалась примесь железа до 1 \%. 


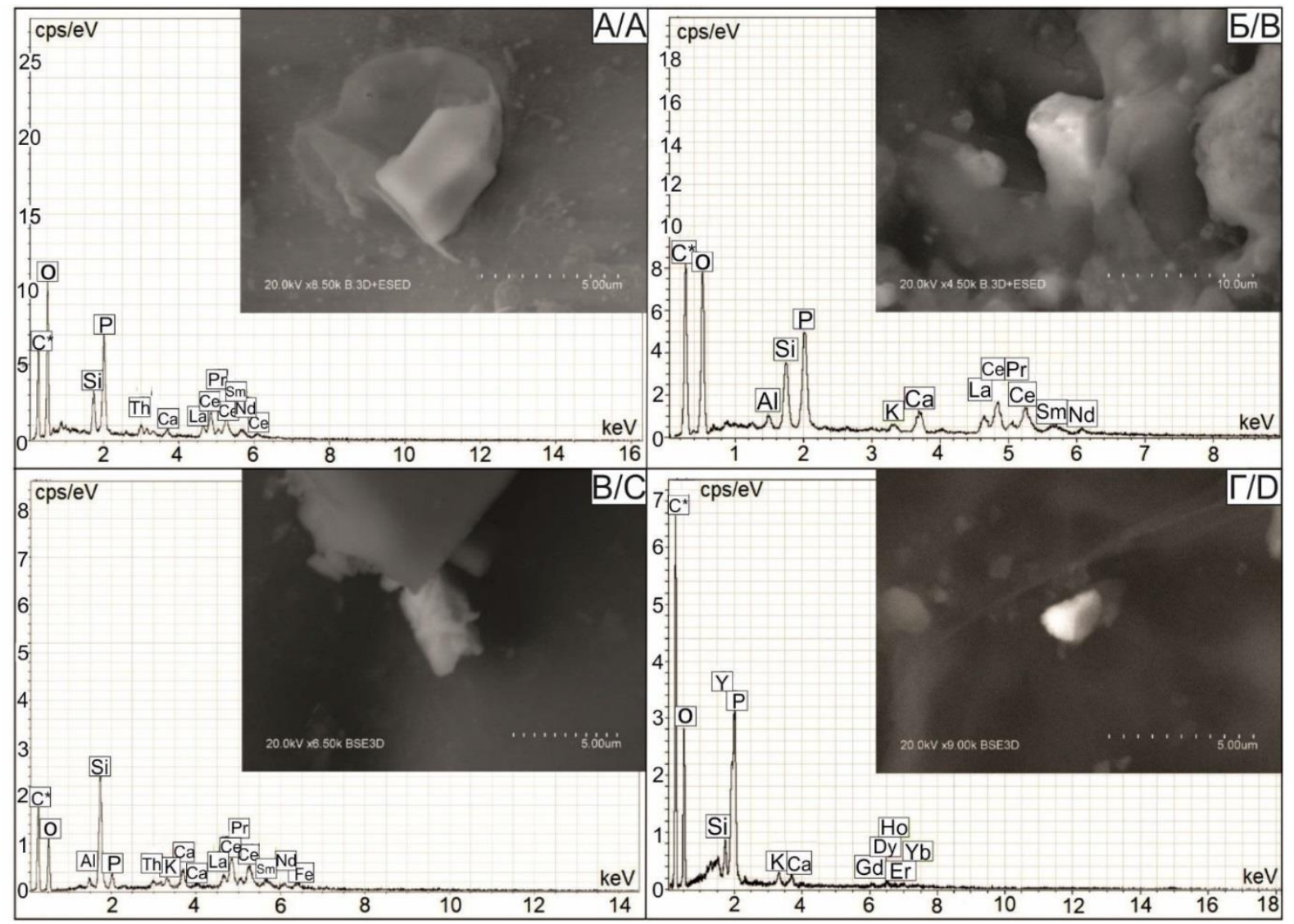

Pис. 3. Формы нахождения редкоземельных минералов на поверхности листа тополя и их энергодисперсионные спектры: А) Хабаровск; Б) Колпашево; В) Северобайкальск; Г) Стрежевой

Fig. 3. Rare-earth minerals deportment on the surface of a poplar leaf and its EDX spectrums: A) Khabarovsk; B) Kolpashevo; C) Severobaykalsk; D) Strezhevoy

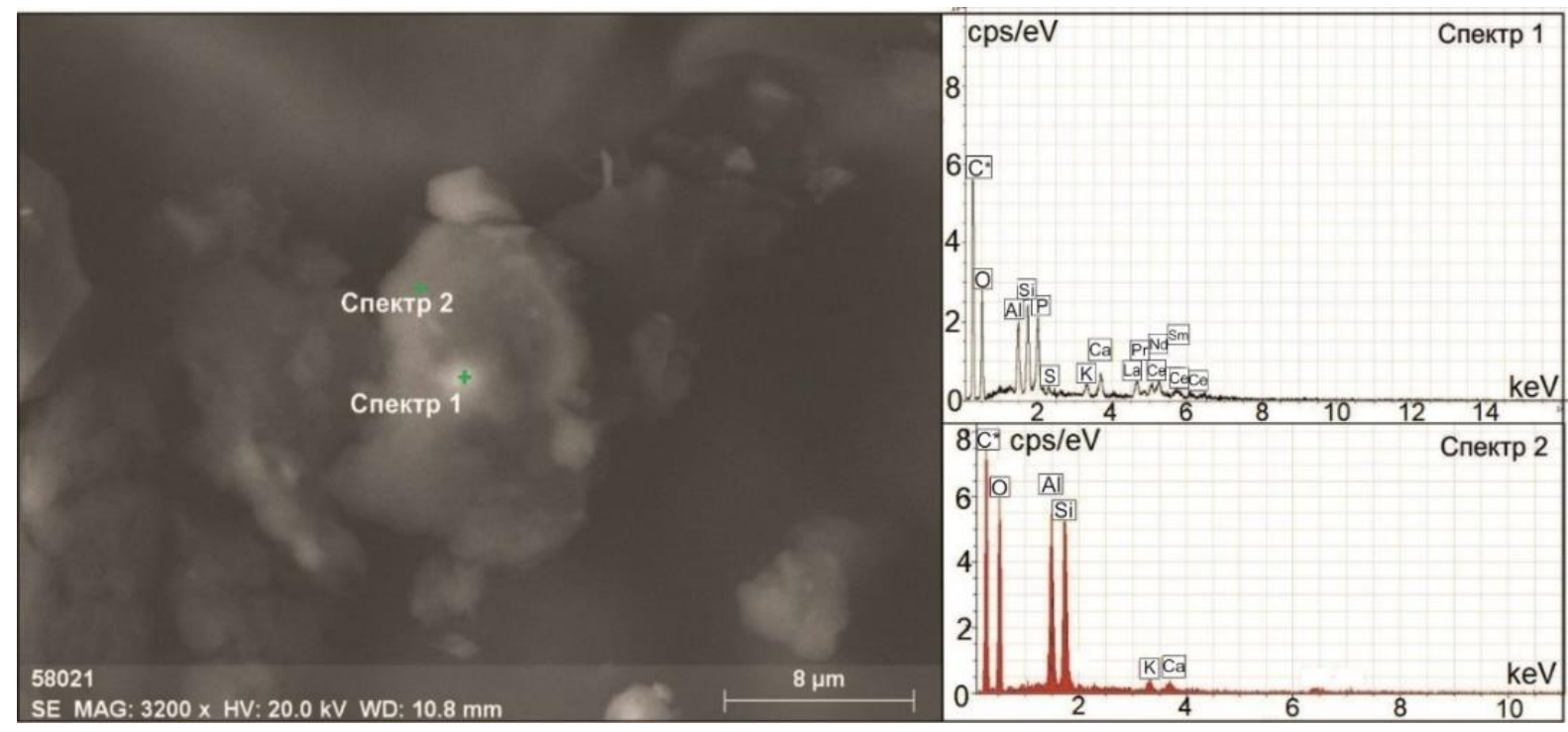

Pис. 4. Редкоземельный минерал в алюмосиликатной частице и ее энергодисперсионные спектры (2. Хабаровск)

Fig. 4. Rare-earth mineral in aluminum silicate particle and its EDX spectrums (Khabarovsk) 


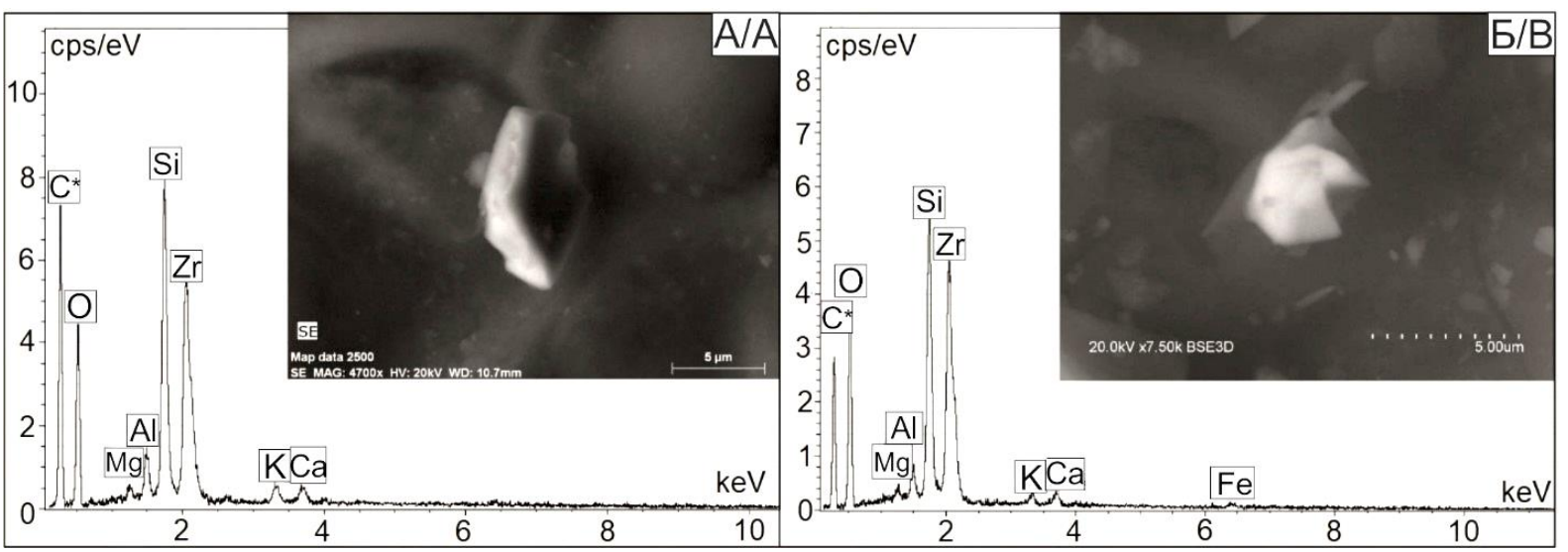

Рис. 5. Результаты электронно-микроскопических исследований минеральных частии циркона на поверхности листьев тополя и их энергодисперсионные спектры: А) Хабаровск; Б) Северобайкальск

Fig. 5. Results of electron microscopic studies of zircon mineral particles on the surface of poplar leaves and its EDX spectrums: A) Khabarovsk; B) Severobaykalsk

\section{Выводы}

1. $\mathrm{Zr} / \mathrm{Ce}$ отношение является важным индикаторным показателем, позволяющим выявить источники ветрового переноса минеральной пыли. По минералого-геохимическому составу проб выделена группа городов с вероятным преобладанием продуктов ветрового переноса - РЗЭ: Колпашево, Каргасок, Стрежевой, Усть-Баргузин, Северобайкальск, Хабаровск, Комсомольск-на-Амуре, Благовещенск и другие. Характерной особенностью территорий этих городов является наличие открытых участков и береговых пространств, на которых происходит ветровая дефляция.

\section{СПИСОК ЛИТЕРАТУРЫ}

1. Impact evaluation of environmental factors on respiratory function of asthma patients living in urban territory / L.V. Veremchuk, K. Tsarouhas, T.I. Vitkina, E.E. Mineeva, T.A. Gvozdenko, M.V. Antonyuk, V.N. Rakitskii, K.A. Sidletskaya, A.M. Tsatsakis, K.S. Golokhvast // Environmental Pollution. - 2018. - V. 235. P. 489-496.

2. Катола В.М., Комогорцева В.Е. Пыль: источники образования, ее общая характеристика, пылевые заболевания (краткий обзор) // Бюллетень физиологии и патологии дыхания. - 2018. Вып. 67. - С. 111-116.

3. Экологические риски от влияния токсичных элементов в атмосферном воздухе на основе изучения снежного покрова в районе расположения томской ГРЭС-2 / Н.А. Осипова, А.В. Таловская, Е.А. Филимоненко, Е.Г. Язиков, С.А. Новиков // Известия Томского политехнического университета. Инжиниринг георесурсов. - 2018. - Т. 329. - № 4. - С. 54-69.

4. Effects of neighborhood green space on PM2.5 mitigation: evidence from five megacities in China / M. Chen, F. Dai, B. Yang, S. Zhu // Building and Environment. - 2019. - V. 159. - P. 33-45.

5. Characteristics and environmental significance of rare earth elements in PM2.5 of Nanchang, China / Z. Yang, Y. Ruilian, H. Gongren, L. Xiaohui, L. Xianrong // Journal of rare earths. 2017. - V. 35. - № 1. - P. 98-106.

6. Микроразмерное загрязнение атмосферы города Благовещенска / К.С. Голохваст, В.В. Кодинцев, И.Э. Памирский, В.В. Чайка, Р.А. Белоус // Бюллетень физиологии и патологии дыхания - 2016. - Вып. 60. - С. 52-56.

7. Ревич А.Б. Мелкодисперсные взвешенные частишы в атмосферном воздухе и их воздействие на здоровье жителей мегаполисов // ПЭММЭ. - 2018. - Т. 29. - № 3. - С. 53-78.
2. На поверхности листьев тополя зафиксированы природные минералы, представленные преимущественно фосфатами легких РЗЭ, а также тяжелыми РЗЭ и цирконом. Эти данные позволяют говорить о влиянии ветрового переноса минеральных частиц с береговых пространств крупных рек и озер.

3. Листья тополя являются биогеохимическим планшетом, способным улавливать и задерживать минеральные частицы пыли из атмосферы. Прослежена взаимосвязь между распределением микроэлементов в частицах пыли на поверхности листьев и влиянием ветровой дефляции. Микроэлементный анализ листьев позволяет получать информацию о составе, генезисе атмосферной пыли, рассеянной в окружающей среде.

8. Biomonitoring of airborne metals using tree leaves: protocol for biomonitor selection and spatial trend / Y. Hajizadeh, M. Mokhtari, M. Faraji, A. Abdolahnejad, A. Mohammadi // MethodsX. 2019. - V. 6. - P. 1694-1700.

9. Волкова Ю.В. Скорость начала трогания и транспорт частиц грунта при ветровой эрозии почв: автореф. дис. ... канд. техн. наук. - СПб., 2002. - 19 с

10. Шойгу С.К., Владимиров В.А., Воробьев Ю.Л. Безопасность России. Защита населения и территорий от чрезвычайных ситуаций природного и техногенного характера. - М.: МГФ «Знание», 1999. - $588 \mathrm{c}$.

11. Глушко А.Я. Влияние водной и ветровой эрозии на земельный фонд юга европейской части России // Естественные и точные науки. - 2010. - № 1. - С. 75-85.

12. Абумуслимов А.А. Анализ эколого-генетических рядов растительных сообществ для оценки дефляции и эволюции пустынь северо-западного Прикаспия: афтореф. дис. ... канд. биол. наук. - Махачкала, 2004. -28 с.

13. Рулев А.С., Беляков А.М., Сарычев А.Н. Исследование проявления дефляции почв в условиях Волгоградской области // Известия Нижневолжского агроуниверситетского комплекca. - 2016. - T. 42. - № 2. - C. 101-107.

14. Куанышбаев С.Б., Гурьянова О.Н. Ветровая эрозия на территории Костанайской области // Вестник КГПИ.-2008.T. 10. - № 2. - C. 178-184.

15. Дьяченко А.Е., Макарычев Н.Г. Дефляция почв и агромелиоративные мероприятия в Северном Казахстане. - М.: АН CCCP, 1959. - $112 \mathrm{c}$.

16. Temporally explicit life cycle assessment as an environmental performance decision making tool in rare earth project development / R. Pell, F. Walla, X. Yan, J. Li, Z. Zeng // Minerals Engineering. - 2019. - V. 135. - P. 64-73. 
17. Mineralogy and geochemistry of atmospheric particulates in western Iran / H. Ahmady-Birgani, H. Mirnejad, S. Feiznia, K. McQueen // Atmospheric Environment. - 2015. - V. 119.P. 262-272.

18. Кожевникова Н.М. Получение модифицированных лантаном природных цеолитов - потенциальных стимуляторов регенерации живых тканей // Химия в интересах устойчивого развития. - 2011. - № 9. - С. 207-211.

19. Маладаев А.А. Влияние лантана на биологическую активность почв, урожай и качество растений: дис. ... канд. биол. наук. - Улан-Удэ, 2007. - 125 c.

20. Boldyreva A.A. Lanthanum potentiates GABA-activated currents in rat pyramidal neurons of CA1 hippocampal field // Bulletin of Experimental Biology and Medicine.-2005.- V. 140.- № 4.P. 403-405.

21. Rare earth elements (REEs) as pollution indicator in sediment of Linggi River, Malaysia / M.S. Elias, S. Ibrahim, K. Samuding, N. Kantasamya, S.A. Rahman, A. Hashim // Applied Radiation and Isotopes. - 2019. - V. 151. - P. 116-123.

22. Lanthanide particles in the lung of a printer / A. Dufresne, G. Krier, J.F. Muller, B. Case, G. Perrault // The Science of the Total Environment. - 1994. - V. 151. - № 3. - P. 249-252.

23. Hirano S., Suzuki K.T. Exposure, metabolism, and toxicity of rare earths and related compounds // Environ. Health Perspect. 1996. - V. 104. - P. 85-95.

24. Trace elements in tissues of a worker affected by rare earth pneumoconiosis. A study carried out by neutron activation analysis / R. Pietra, E. Sabbioni, L. Ubertalli, E. Orvini, G. Vocaturo, F. Colombo, M. Zanoni // Journal of Radioanalytica and Nuclear Chemistry. - 1985. - V. 92. - № 2. - P. 247-259.

25. Determination of Rare Earth Elements in multi-year highresolution Arctic aerosol record by double focusing Inductively Coupled Plasma Mass Spectrometry with desolvation nebulizer inlet system / F. Giardi, R. Traversi, S. Becagli, M. Severi, L. Caiazzo, C. Ancillotti, R. Udisti // Science of the Total Environment. - 2018. - V. 613-614. - P. 1284-1294.

26. Геохимические особенности элементного состава листьев тополя урбанизированных территорий / Д.В. Юсупов, Л.П. Рихванов, Н.В. Барановская, А.Р. Ялалтдинова // Известия Томского политехнического университета. Инжиниринг георесурсов. - 2016. - Т. 327. - № 6. - С. 25-36.

27. Rare earth elements in poplar leaves as indicators of geological environment and technogenesis / D.V. Yusupov, N.V. Baranovskaya, Yu.V. Robertus, V.V. Radomskaya, L.M. Pavlova, A.F. Sudyko, L.P. Rikhvanov // Environmental Science and Pollution Research. 2020. - V. 27. - P. 27111-27123.

28. Tree rings reveal the reduction of $\mathrm{Cd}, \mathrm{Cu}, \mathrm{Ni}$ and $\mathrm{Pb}$ pollution in the central region of São Paulo, Brazil / G.M. Locosselli, K. Chacon-Madrid, M.A.Z. Arruda, E.P. Camargo, T.C. Moreira, C.D.S. Andre, P.A. Andre, J.M. Singer, P.H.N. Saldiva, M.S. Buckeridge // Environmental Pollution. - 2018. - V. 242.P. $320-328$.

29. Should we see urban trees as effective solutions to increasing ozone levels in cities? / P. Sicard, E. Agathokleous, V. Araminiene, E. Carrari, Y. Hoshika, A. de Marco, E. Paoletti // Environmental Pollution. - 2018. - V. 243. - P. 163-176.
30. Influence of rainfall duration and intensity on particulate matter removal from plant leaves / X. Xu, Z. Zhang, L. Bao, Li. Moa, X. Yu, D. Fan, X. Lun // Science of the Total Environment. 2017. - V. 609 - P. 11-16.

31. PM2.5-bound SO42- absorption and assimilation of poplar and its physiological responses to PM2.5 pollution / Q. Yang, H. Wang, J. Wang, M. Lu, C. Liu, X. Xia, W. Yin, H. Guo // Environmental and Experimental Botany. - 2018. - V. 153. - P. 311-319.

32. Голохваст К.А. Нано- и микроразмерные частицы атмосферных взвесей и их экологический эффект (на примере городов юга Дальнего Востока): дис. ... д-ра биол. наук. Владивосток, 2014. - $310 \mathrm{c}$

33. Радиоактивные элементы (торий, уран) в листьях тополя на урбанизированных территориях и их индикаторная роль / Д.В. Юсупов, Л.П. Рихванов, А.Ф. Судыко, Н.В. Барановская, Л.А. Дорохова // Разведка и охрана недр. - 2019. - № 2. C. 61-68

34. Characterization of PM10 and PM2.5 Source Profiles of Fugitive Dust in Zhengzhou, China / N. Jiang, Z. Dong, Y. Xu, F. Yu, S. Yin, R. Zhang, X. Tang // Aerosol and Air Quality Research. 2018. - V. 18. - P. 314-329.

35. Anderson C.R., Pederson K. In Situ growth of Gallionella biofilms and partitioning of lanthanides and actinides between biological material and ferric oxyhydroxides // Geobiology. - 2003. - V. 1. P. $169-178$

36. Погода в Благовещенске // Расписание погоды, 2004. URL: www.rp5.ru (дата обращения 15.05.2019).

37. Tian S., Liang T., Li K. Fine road dust contamination in a mining area presents a likely air pollution hotspot and threat to human health // Environment International. - 2019. - V. 128. - P. 201-209.

38. Settled iron-based road dust and its characteristics and possible association with detection in human tissues / K. Cabanova, K. Hrabovska, P. Matejkova, K. Dedkova, V. Tomasek, J. Dvorackova, J. Kukutschova // Environmental Science and Pollution Research. - 2018. - V 26. - № 3. - P. 1-10.

39. Source and path identification of metals pollution in a mining area by PMF and rare earth element patterns in road dust / S.H. Tian, T. Liang, K.X. Li, L.Q. Wang // Science of the Total Environment - 2018. - V. 633. - P. 958-966.

40. Многомерный статистический анализ содержаний элементов в снеговом покрове г. Благовещенска / И.В. Радомская, Д.В. Юсупов, Л.М. Павлова, А.Г. Сергеева, Н.А. Бородина // Региональная экология. - 2018. - Т. 52. - № 2. - С. 15-28.

41. Radomskaya V.I., Yusupov D.V., Pavlova L.M. Rare-Earth Elements in the atmospheric precipitation of the city of Blagoveshchensk // Geochemistry international. - 2018. - V. 56. № 2. - P. 189-198.

42. Главные рудообразующие минералы аномально богатых руд месторождения Томтор / Е.В. Лазарева, С.М. Жмодик, Н.Л. Добрецов, А.В. Толстов, Б.Л. Щербов, Н.С. Карманов, Е.Ю. Герасимов, А.В. Брянская // Геология и геофизика. 2015. - T. 56. - № 6. - С. 1080-1115.

43. Пиневич А.В. Микробиология железа и марганца. - СПб.: Изд-во С.-Пб унив., 2005. - 372 с.

Поступила 15.10.2020 2.

\section{Информация об авторах}

Дорохова Любовь Александровна, аспирант отделения геологии Инженерной школы природных ресурсов, Национальный исследовательский Томский политехнический университет.

Юсупов Дмитрий Валерьевич, кандидат геолого-минералогических наук, доцент кафедры геологии и природопользования, Амурский государственный университет; доцент отделения геологии инженерной школы природных, Национальный исследовательский Томский политехнический университет.

Рихванов Леонид Петрович, доктор геолого-минералогических наук, профессор отделения геологии Инженерной школы природных ресурсов, Национальный исследовательский Томский политехнический университет. 
UDC 550.422:546.54-:55:502.4:630*238

\title{
GEOCHEMICAL AND MINERAL INDICATORS OF DEFLATION IN URBAN AREAS USING POPLAR LEAVES
}

\author{
Lyubov A. Dorokhova1, \\ liubov.ad@yandex.ru \\ Dmitry V. Yusupov1,2, \\ yusupovd@mail.ru \\ Leonid P. Rikhvanov $^{1}$ \\ 1 National Research Tomsk Polytechnic University, \\ 30, Lenin avenue, Tomsk, 634050, Russia. \\ 2 Amur State University, \\ 21, Ignatievskoe highway, Blagoveshchensk, 675027, Russia.
}

Relevance of the work is caused by the need to assess the impact of natural and technogenic environmental factors affecting the quality of atmospheric air, soil and vegetation as well as the health of the population in urban areas. Deflation or wind erosion is soil destruction under the influence of wind. The territories in the south of Western and Eastern Siberia, the Far East, located in the valleys of large rivers, as well as in agricultural steppe regions, are especially affected by it. Winds during the periods without precipitation, dry sandy deposits along river banks, wind-impact slopes, soils of light particle size distribution, gently sloping terrain, creating conditions for unhindered movement of air flows, contribute to wind erosion. It can be local in nature, in a more active form of dust storms cause great harm to the economy.

The aim of the research is to evaluate the role of atmospheric dust pollution in urban areas by studying the elemental composition of micro-sized particles using poplar leaves as a biogeochemical tablet.

The methods. The elemental composition of ash samples of balsamic poplar leaves (Populus balsamifera L.) was studied by instrumental neutron activation analysis, ICP-MS and -AES; the elemental composition of micro-sized particles on the leaf surface - at a Hitachi S-3400N scanning electron microscope using a Bruker XFlash 4010 energy dispersive spectrometer; data processing was carried out using of the multivariate statistical methods.

The results. The paper presents the results of the study of mineral dust from surface air, accumulated on the surface of poplar leaves. $A$ significant contribution to the distribution of rare-earth elements on the territory of settlements located on the banks of the Ob River (Kolpashevo, Kargasok, Strezhevoy; Lake Baikal (Ust-Barguzin and Severobaykalsk), Amur River (Blagoveshchensk, Khabarovsk, Komsomolsk-on-Amur) makes a dust transfer as a result of deflation in the directions of the prevailing winds. Using the indicator $\mathrm{Zr} / \mathrm{Ce}$ ratio, urbanized areas with active wind erosion were determined. Mineral particles of light and heavy rare earth elements, mainly phosphates (monazite and xenotime), as well as zircons, were found.

\section{Key words:}

Wind erosion, rare earth elements, Zr/Ce ratio, geochemical indicator, monazite, xenotime, zircon, poplar leaves, neutron activation analysis, SEM-EDS.

\section{REFERENCES}

1. Veremchuk L.V., Tsarouhas K., Vitkina T.I., Mineeva E.E., Gvozdenko T.A., Antonyuk M.V., Rakitskii V.N., Sidletskaya K.A., Tsatsakis A.M., Golokhvast K.S. Impact evaluation of environmental factors on respiratory function of asthma patients living in urban territory. Environmental Pollution, 2018, vol. 235, pp. 489-496.

2. Katola V.M., Komogorceva V.E. Dust: sources of formation, its general characteristics and dust diseases (brief review). Bulletin of Physiology and Respiratory Pathology, 2018, vol. 67, pp. 111-116. In Rus.

3. Osipova N.A., Talovskaya A.V., Filimonenko E.A., Yazikov E.G., Novikov S.A. Environmental risks from the influence of toxic elements in the air based on the study of snow cover in the area of Tomsk hydroelectric station 2. Bulletin of the Tomsk Polytechnic University. Geo Assets Engineering, 2018, vol. 329, no. 4, pp. 54-69. In Rus.

4. Chen M., Dai F., Yang B., Zhu S. Effects of neighborhood green space on $\mathrm{PM}_{2.5}$ mitigation: Evidence from five megacities in China Building and Environment, 2019, vol. 159, pp. 1-43.

5. Yang Z., Ruilian Y., Gongren H., Xiaohui L., Xianrong L. Characteristics and environmental significance of rare earth elements in $\mathrm{PM}_{2.5}$ of Nanchang, China. Journal of rare earths, 2017, vol. 35, no. 1, pp. 98-106

6. Golokhvast K.S., Kodincev V.V., Pamirskij I.E., Chajka V.V., Belous R.A. Microdimensional air pollution of atmosphere in Blagoveshchensk. Bulletin of respiratory physiology and pathology, 2016, vol. 60, pp. 52-56. In Rus.
7. Revich A.B. Fine suspended particulates in ambient air and their health effect in megalopolises. PEMME, 2018, vol. 29, no. 3, pp. 53-78. In Rus.

8. Hajizadeh Y., Mokhtari M., Faraji M., Abdolahnejad A., Mohammadi, A. Biomonitoring of airborne metals using tree leaves: protocol for biomonitor selection and spatial trend. MethodsX, 2019, vol. 6, pp. 1694-1700.

9. Volkova Yu.V. Skorost nachala troganiya i transport chastic grunta pri vetrovoy erozii pochv. Avtoreferat. Dis. Kand. nauk [The start velocity and transport of soil particles during wind erosion of soils. Cand. Diss. Abstract]. St-Petersburg, 2002. 19 p.

10. Shoigu S.K., Vladimirov V.A., Vorobiev Yu.L. Bezopasnost Rossii. Zashchita naseleniya i territoriy ot chrezvychaynykh situatsiy prirodnogo i tekhnogennogo kharaktera [The security of Russia. Protection of the population and territories from natural and technogenic character]. Moscow, Znanie Publ., 1999. 588 p.

11. Glushko A.Ya. Vliyanie vodnoy i vetrovoy erozii na zemelny fond yuga evropeyskoy chasti Rossii [The influence of water and wind erosion on the land fund of the south of the European part of Russia]. Natural and exact sciences, 2010, no. 1, pp. 75-85. In Rus.

12. Abumuslimov A.A. Analiz ekologo-geneticheskikh ryadov rastitelnykh soobshchestv dlya otsenki deflyatsii i evolyutsii pustyn severo-zapadnogo Prikaspiya. Aftoreferat Dis. Kand. nauk [Analysis of ecological-genetic series of plant communities to assess deflation and evolution of deserts of the northwestern Caspian. Cand. Diss. Abstract]. Mahachkala, 2004. 28 p. 
13. Rulev A.S., Belyakov A.M., Sarychev A.N. Soil deflation occurrence research in Volgograd region conditions. Bulletin of the Lower Volga Agro-University Complex, 2016, vol. 42, no. 2, pp. 101-107. In Rus.

14. Kuanyshbaev S.B., Guryanova O.N. Vetrovaya eroziya na territorii Kostanayskoy oblasti [Wind erosion in the Kostanay region] Vestnik KGPI, 2008, vol. 10, no. 2, pp. 178-184.

15. Dyachenko A.E., Makarychev N.G. Deflyatsiva pochv i agromeliorativnye meropriyatiya v Severnom Kazahstane [Soil deflation and land reclamation measures in Northern Kazakhstan]. Moscow, AN SSSR Publ., 1959. $112 \mathrm{p}$

16. Pell R., Walla F., Yan X., Li J., Zeng Z. Temporally explicit life cycle assessment as an environmental performance decision making tool in rare earth project development. Minerals Engineering, 2019, vol. 135, pp. 64-73.

17. Ahmady-Birgani H., Mirnejad H., Feiznia S., McQueen K. Mineralogy and geochemistry of atmospheric particulates in western Iran Atmospheric Environment, 2015, vol. 119, pp. 262-272.

18. Kozhevnikova N.M. Poluchenie modifitsirovannykh lantanom prirodnykh tseolitov - potentsialnykh stimulyatorov regeneratsii zhivykh tkaney [Obtaining lanthanum-modified natural zeolites potential stimulants for the regeneration of living tissues]. Khimiya v interesakh ustoychivogo razvitiva, 2011, no. 9, pp. 207-211.

19. Maladaev A.A. Vliyanie lantana na biologicheskuyu aktivnost pochv, urozhay i kachestvo rasteniy. Dis. Kand. nauk [The effect of lanthanum on the biological activity of soils, crop and plant quality. Cand. Diss.]. Ulan-Ude, 2007. 125 p.

20. Boldyreva A.A. Lanthanum potentiates GABA-activated currents in rat pyramidal neurons of CA1 hippocampal field. Bulletin of Experimental Biology and Medicine, 2005, vol. 140, no. 4, pp. 403-405.

21. Elias M.S., Ibrahim S., Samuding K., Kantasamya N., Rahman S.A., Hashim A. Rare earth elements (REEs) as pollution indicator in sediment of Linggi River, Malaysia. Applied Radiation and Isotopes, 2019, vol. 151, pp. 116-123.

22. Dufresne A., Krier G., Muller J.F., Case B., Perrault G. Lanthanide particles in the lung of a printer. The Science of the Total Environment, 1994, vol. 151, no. 3, pp. 249-252.

23. Hirano S., Suzuki K.T. Exposure, metabolism, and toxicity of rare earths and related compounds. Environmental Health Perspect, 1996, vol. 104, pp. 85-95.

24. Pietra R., Sabbioni E., Ubertalli L., Orvini E., Vocaturo G., Colombo F., Zanoni M. Trace elements in tissues of a worker affected by rare earth pneumoconiosis. A study carried out by neutron activation analysis. Journal of Radioanalytical and Nuclear Chemistry, 1985, vol. 92, no. 2, pp. 247-259.

25. Giardi F., Traversi R., Becagli S., Severi M., Caiazzo L., Ancillotti C., Udisti R. Determination of Rare Earth Elements in multi-year high-resolution Arctic aerosol record by double focusing Inductively Coupled Plasma Mass Spectrometry with desolvation nebulizer inlet system. Science of the Total Environment, 2018, vol. 613-614, pp. 1284-1294.

26. Yusupov D.V., Rikhvanov L.P., Baranovskaya N.V., Yalaltdinova A.R. Geochemical features of the elemental composition of poplar leaves in urban areas. Bulletin of the Tomsk Polytechnic University. Geo Assets Engineering, 2016, vol. 327, no. 6, pp. 25-36. In Rus.

27. Yusupov D.V., Baranovskaya N.V., Robertus Yu.V., Radomskaya V.V., Pavlova L.M., Sudyko A.F., Rikhvanov L.P. Rare earth elements in poplar leaves as indicators of geological environment and technogenesis. Environmental Science and Pollution Research, 2020, vol. 27, pp. 27111-27123.

28. Locosselli G.M., Chacon-Madrid K., Arruda M.A.Z., Camargo E.P., Moreira T.C., Andre C.D.S., Andre P.A., Singer J.M., Saldiva P.H.N., Buckeridge M.S., Tree rings reveal the reduction of $\mathrm{Cd}, \mathrm{Cu}, \mathrm{Ni}$ and $\mathrm{Pb}$ pollution in the central region of São Paulo, Brazil. Environmental Pollution, 2018, vol. 242, pp. 320-328

29. Sicard P., Agathokleous E., Araminiene V., Carrari E., Hoshika Y., De Marco A., Paoletti E. Should we see urban trees as effective solutions to increasing ozone levels in cities? Environmental Pollution, 2018, vol. 243, pp. 163-176.

30. Xu X., Zhang Z., Bao L., Moa Li., Yu X., Fan D., Lun X. Influence of rainfall duration and intensity on particulate matter removal from plant leaves. Science of the Total Environment, 2017, vol. 609, pp. 11-16.

31. Yang Q., Wang H., Wang J., Lu M., Liu C., Xia X, Yin W., Guo H. $\mathrm{PM}_{2.5}$-bound $\mathrm{SO}_{4}{ }^{2-}$ absorption and assimilation of poplar and its physiological responses to $\mathrm{PM}_{2.5}$ pollution. Environmental and Experimental Botany, 2018, vol. 153, pp. 311-319.

32. Golohvast K.A. Nano- $i$ mikrorazmernye chastitsy atmosfernykh vzvesey i ikh ekologicheskiy effekt (na primere gorodov yuga Dalnego Vostoka). Dis. Dokt. nauk [Nano- and micro-sized particles of atmospheric suspensions and their environmental effect (on the example of cities in the south of the Far East). Cand. Diss.]. Vladivostok, 2014. $310 \mathrm{p}$

33. Yusupov D.V., Rihvanov L.P., Sudyko A.F., Baranovskaya N.V., Dorohova L.A. Radioactive elements (thorium, uranium) in poplar leaves in urban areas and their indicator role. Exploration and mineral protection, 2019, no. 2, pp. 61-68. In Rus.

34. Jiang N., Dong Z., Xu Y., Yu F., Yin S., Zhang R., Tang X. Characterization of PM10 and PM2.5 Source Profiles of Fugitive Dust in Zhengzhou, China. Aerosol and Air Quality Research, 2018, vol. 18 , pp. 314-329.

35. Anderson C.R., Pederson K. In Situ growth of Gallionella biofilms and partitioning of lanthanides and actinides between biological material and ferric oxyhydroxides. Geobiology, 2003, vol. 1, pp. $169-178$.

36. Pogoda v Blagoveshchenske [Weather in Blagoveshchensk]. Raspisanie pogody, 2004. Available at: www.rp5.ru (accessed 15 May 2019)

37. Tian S., Liang T., Li K. Fine road dust contamination in a mining area presents a likely air pollution hotspot and threat to human health. Environment International, 2019, vol. 128, pp. 201-209.

38. Cabanova K., Hrabovska K., Matejkova P., Dedkova K., Tomasek V., Dvorackova J., Kukutschova J. Settled iron-based road dust and its characteristics and possible association with detection in human tissues. Environmental Science and Pollution Research, 2018, vol. 26, no. 3, pp. 1-10.

39. Tian S.H., Liang T., Li K.X., Wang L.Q. Source and path identification of metals pollution in a mining area by PMF and rare earth element patterns in road dust. Science of the Total Environment, 2018, vol. 633, pp. 958-966.

40. Radomskaya I.V., Yusupov D.V., Pavlova L.M., Sergeeva A.G., Borodina N.A. Multivariate statistical analysis of element contents in the snow cover of Blagoveshchensk. Regional Ecology, 2018, vol. 52, no. 2, pp. 15-28. In Rus.

41. Radomskaya V.I., Yusupov D.V., Pavlova L.M. Rare-Earth Elements in the Atmospheric Precipitation of the city of Blagoveshchensk. Geochemistry international, 2018, vol. 56, no. 2, pp. 189-198.

42. Lazareva E.V., Zhmodik S.M., Dobrecov N.L., Tolstov A.V., Shcherbov B.L., Karmanov N.S., Gerasimov E.Yu., Bryanskaya A.V. Major minerals of abnormally high-grade ores of the tomtor deposit (Arctic Siberia). Geology and geophysics, 2015, vol. 56, no. 6, pp. 1080-1115. In Rus.

43. Pinevich A.V. Mikrobiologiya zheleza i margantsa [Microbiology of iron and manganese]. St.-Petersburg, St.-Petersburg University Publ., 2005. $372 \mathrm{p}$

Received: 15 October 2020.

Information about the authors

Lyubov A. Dorokhova, post-graduate student, National Research Tomsk Polytechnic University.

Dmitry V. Yusupov, associate professor, National Research Tomsk Polytechnic University; Cand. Sc., assistant professor, Amur State University.

Leonid P. Rikhvanov, Dr. Sc., professor, National Research Tomsk Polytechnic University. 